\title{
How EFL Learners Maintain Motivational Factors and Positive Attitudes during COVID-19 Pandemic: A Qualitative Study
}

\author{
Reza Anggriyashati Adara \\ Universitas Islam 45 Bekasi \\ reza.adara@gmail.com \\ Novita Puspahaty \\ Universitas Islam 45 Bekasi \\ novita@englit45bekasi.org
}

\begin{abstract}
The present study aims to analyze how a group of EFL learners in Indonesia maintained their motivation and positive attitudes toward English learning during the Covid-19 pandemic. The present study applied a qualitative study by conducting semi-structured interviews with ten respondents. The results suggest that the Covid-19 pandemic has affected the respondents significantly. At the beginning of the Covid-19 pandemic, most respondents were demotivated but they were able to motivate themselves again by reminding themselves of the reasons they learned English in the first place. Those reasons are mostly dominated by extrinsic factors such as their need to get jobs, studying overseas and the benefits of mastering English for their future also motivated the respondents. However, some are still motivated to learn English because they are intrinsically motivated. The results suggest that both intrinsic and extrinsic motivation are needed to maintain learners' motivation and positive attitudes toward language learning. In addition, maintaining personal communication with students during tough times such as the Covid-19 pandemic seems important to be conducted by teachers. By keeping personal communication, teachers can help maintain students' motivation. Besides that, the findings of the present study indicate that the respondents used various methods to maintain their motivation such as using social media to learn English and constantly reminding themselves of their language learning goals.
\end{abstract}

ENGLISH FRANCA: Academic Journal of English Language and Education

Vol. 5, No. 2, 2021, IAIN Curup

P-ISSN 2580-3670, E-ISSN 2580-3689

DOI: $10.29240 /$ ef.v5i2.3398 
In regards to this, teachers should help students by integrating social media into the lessons and providing affirmations that remind students of the benefits of English language mastery.

Keywords: EFL learning, motivation, attitudes, pandemic

\section{INTRODUCTION}

One of the aspects which have been drastically changed during the Covid-19 pandemic is education. To prevent the transmission of Covid19, schools and informal courses are closed. Instead of real-life classrooms, online learning is implemented. Similar to the other subjects, English is also taught online. However, online learning and teaching may pose challenges to EFL (English as a Foreign Language) learners as ones in Indonesia. Students confront a variety of challenges in this online education, including facility and infrastructure preparedness, learning achievement, and student attitudes (Taufik, et. al, 2020). A study of Famularsih (2020) on students 'experiences in using online learning applications during the Covid-19 pandemic shows slow-speed Internet connection, multiple tasks forced upon students, and lack of interaction between students and lecturers as the main challenges in learning English during the Covid-19 pandemic. The weight of evidence suggests that the changes brought by the Covid-19 pandemic may cause unique challenges to be overcome by teachers and students, especially in the Indonesian EFL learning context.

Related to the above paragraph, besides improving teaching techniques, teachers can overcome teaching challenges by improving their students 'motivation. It is needed because motivation is not only one of the important factors in EFL learning but it also helps improve learners 'attitudes toward EFL learning (Mantiri, 2015; Kazantseva et al., 2016) and ensures the success of language acquisition (Carrió-Pastor \& Mestre, 2014). However, lack of motivation has been reported as one of the main teaching and learning challenges in Indonesia (Hibatullah, 2019; Yulia, 2013). It is why analyzing students 'motivation is important as it will provide more information on how to improve students 'motivation (Adara, 2019). Besides that, the provision of research toward motivation 
Reza Anggriyashati Adara, Novita Puspahaty: How EFL Learners Maintain Motivational

Factors and Positive Attitudes During COVID-19 Pandemic: A Qualitative Study - 279

can give educators more insights on sustaining learners 'interest in EFL learning (Dörnyei, 2014). Thus, despite being a challenge, motivation needs to be maintained and investigated.

The present study aims to investigate how EFL learners in Indonesia maintain their motivation and positive attitudes during the Covid-19 pandemic. By investigating these variables, the present study aims to provide more insights into learners 'strategies to maintain their motivation, especially during critical moments such as the Covid-19 pandemic. Lamb (2016) argues that motivation is influenced by complex internal and contextual factors and can change unpredictably. Several studies have shown how motivation can change when learners are subjected to certain treatments or circumstances. A study by Waninge et al (2014) shows the increase and decrease of learners 'motivation after they were subjected to a course of lessons. In addition, MacIntyre \& Serroul (2015) reports dramatic fluctuations of motivation during various communicative tasks. They found that learners 'motivation can be influenced by basic factors such as the topics of the lessons. It can be said that investigating learners 'motivation periodically is important because it is a subject of change. As one of the life-changing events, the Covid-19 pandemic can change learners 'motivation and attitudes toward EFL learning. It seems important to investigate what or how it has changed learners 'motivation and attitudes. Previous studies such as ones conducted by Famularsih (2020) and Muslimin \& Harintama (2020) who analyzed the effects of online learning during pandemics on students ' motivation, challenges, and alternatives have not specifically investigated how students maintain their motivation and positive attitudes. Therefore, the present study aims to fill the void due to the lack of studies toward learners 'motivation and attitudes during the Covid-19 pandemic, especially in the context of EFL learning in Indonesia. In addition, the present study aims to analyze motivational factors and attitudes of a group of EFL learners in Indonesia to learn English during the Covid-19 pandemic as well as strategies they use to maintain motivation and positive attitudes during the Covid-19 pandemic. 


\section{THEORETICAL FRAMEWORK}

The present section aims to discuss theoretical background and previous studies which underlie the present study.

\section{Learners 'Motivation and Attitudes}

Motivation is one of the important factors which determine the success of EFL learning. In this regard, motivation can be defined as a reason or objective which a person has to behave in a given manner in a given situation (Barak et al, 2015). Furthermore, Gusmuliana, et. al, 2020) stated that motivation is the capacity to devote a significant amount of time and effort to the achievement of organizational goals, based on the potential of the endeavor. In the EFL learning context, a set of learners ' efforts, desires, and attitudes to reach their language learning goals is defined as motivation (Loewen \& Reinders, 2011). Despite being dedicated and capable, a learner might not be able to reach their language learning goals without sufficient motivation (Adara, 2020). Due to its importance, numerous theories have been posited to describe it. One of them is Self-Identification Theory (SDT) by Deci \& Ryan (1985). Their theory maintains a tenet of distinction between intrinsic and extrinsic motivation. While intrinsic motivation refers to a state of being where a student learns a target language due to his/her interest, and extrinsically motivated student is influenced by external circumstances such as peers, teachers, family, economic goals, or else. Thus, their theory posits the importance of improving extrinsic motivation such as providing better learning environments or teaching methods to improve intrinsic motivation. It can be said that SDT theory argues that both intrinsic and extrinsic motivation affect each other.

Motivation and attitudes are two inseparable aspects that determine success in EFL learning (Ellis, 2006). In this regard, an attitude refers to the way of thinking, feeling, or behaving which influences how someone acts in certain ways (Nafi et al, 2016). Positive attitudes toward language learning help students to achieve their language learning goals (Dörnyei \& Csizér, 2002), and students 'motivation toward language learning can be determined from their attitudes (Bradford, 2007). Students 'attitudes can be a predictor of their performance in language 
acquisition (Nafi et al,2016). Numerous studies show that students with positive attitudes will be more successful than ones with negative attitudes (Bidin et al, 2009; Thang et al, 2011). The weight of evidence suggests that motivation and attitudes are two important factors in EFL learning.

Numerous studies have investigated both motivation and attitudes in EFL learning in various learning situations. Yang's (2012) study on attitudes and motivation toward EFL learning among a group of students in Malaysia shows a correlation between positive attitudes toward the target language and a high level of motivation. In addition, the participants were motivated by both intrinsic and extrinsic factors. A study by Mat (2014) investigates the attitudes and motivation of a group of Malaysian EFL learners. The results of his study suggest that the participants are highly motivated, and have positive attitudes toward English learning. In addition, Fandiño et al (2019) study on motivational factors of a group of college students in Colombia to learn English through e-learning shows that external factors can heavily influence the participants. Besides that, Dincer \& Yesilyurt's (2017) study on the relationship between EFL learners 'motivation to speak and autonomous support of teachers indicates a correlation between intrinsic and extrinsic motivation as intrinsically motivated students can still be heavily influenced by their teachers 'performances. The above studies show that attitudes and motivation correlate with each other and are influenced by both intrinsic and extrinsic factors.

\section{RESEARCH METHODOLOGY Research Design}

The present study applies a qualitative study to obtain its results. Nassaji (2015) argues that the qualitative method is more suited for analyzing L2 classrooms because experimental research may lead to the generalizability of its findings that can be difficult to be found in real-life classrooms. 


\section{Respondents}

The respondents of the present study are ten college students majoring in English literature from a private university in Bekasi, Indonesia. The sampling used in the present study is convenience sampling due to the Covid-19 pandemic.

\section{Data Collection and Analysis}

As it aims to provide an insight toward students' motivation and attitudes toward language learning during the Covid-19 pandemic, the present study uses interviews to examine motivational factors and attitudes. In regards to the present study, semi-structured interviews were conducted in English through WhatsApp, a chatting application. The interviews lasted around an hour each. Although the respondents were encouraged to speak up their opinions and experience regarding their motivation and attitudes toward language learning during the Covid-19 pandemic, there is a list of questions set as a guide. Following are the questions:

1. What motivates you the most to learn English during the Covid-19 pandemic?

2. How do you feel about learning English during the Covid-19 pandemic?

3. How do you maintain your motivation to learn English during the Covid-19 pandemic?

The interviews 'results were transcribed and checked by the respondents to see their reliability. In addition, as suggested by Révész (2012), another researcher transcribed part of the material to check its reliability. Collected data is analyzed through coding. In regards to the present study, transcribing results were coded into several categories namely motivation, attitudes toward language learning, and strategies to maintain motivation during the Covid-19 pandemic. 


\section{RESULTS AND DISCUSSION \\ Results}

The present section aims to discuss the results of the present study. The results of the present study show that most respondents are still motivated to learn English and have positive attitudes toward the English learning process during the Covid-19 pandemic. Following are several factors which make them learn English during the Covid-19 pandemic:

\section{Extrinsic factors:}

\section{Getting better jobs}

Few respondents commented that they are still motivated to learn English because they want to get better jobs. Following are the comments of some respondents:

"My motivation to learn English is because I want to be a tour guide." (Respondent 7)

"I learn English for my better job because I want to work in an international company. Learning English also helps me to understand many things." (Respondent 8)

\section{Communicating with people from different countries}

One of the factors which motivate the respondents to learn English is because they can use English to communicate with people from different countries.

"In my fandom life, the rest of information from my favorite people mostly are translated in English. So, I have to keep learning English to understand the information." (Respondent 6)

"Besides that, English also makes it easier for me to communicate and also helps others communicate." (Respondent 9) 


\section{Studying abroad}

Several respondents also said that they were motivated to learn English during the Covid-19 pandemic because they want to study abroad. Following are their comments:

"One of my biggest motivations to still learn English is, I won't go abroad for studying." (Respondent 10)

"My dream of going to school in England is one of the strongest motivations for learning my English." (Respondent 9)

The findings of the present study also suggest that most respondents have positive attitudes toward English learning despite being in the middle of a pandemic. Following are some comments which reflect their attitudes toward EFL learning:

"I find myself so intriguing to learn English, even if I already learned the previous subject. There [is] always something you were missing or forgotten and it's so refreshing to learn it again." (Respondent 1)

"Learning English is very happy because with this I can meet many friends from various countries." (Respondent 3)

"I am always enthusiastic when learning English." (Respondent 7)

Despite being in the middle of the Covid-19 pandemic, the above comments suggest that most respondents have positive attitudes toward EFL learning. It is surprising because the Covid-19 pandemic is reported to bring several hurdles to EFL learning. The findings of Hartshorn \& McMurry's (2020) study illustrate that the pandemic brought new stressors to teachers and students. As their anxiety toward the pandemic grew, they became less concerned with the teaching and learning process. In addition, online learning becomes a challenge for teachers and students, resulting in less language development especially in speaking skills due to the lack of interaction. Nevertheless, the respondents of the 
Reza Anggriyashati Adara, Novita Puspahaty: How EFL Learners Maintain Motivational

Factors and Positive Attitudes During COVID-19 Pandemic: A Qualitative Study - 285

present study are still able to maintain a high level of positive attitudes toward language learning.

Related to the level of positive attitudes shown by the respondents of the present study, several factors may influence it. A study by Ngo et al. (2017) on the differences in motivation level between non-English-major and English-major students suggests that English-major students show higher levels of intrinsic motivation than their non-English-major counterparts. They maintain that in contrast to their counterparts, English-major-students have prepared themselves to learn English as their major. In regards to the present study, like English literature students, the respondents of the present study seem to have more positive attitudes toward language learning because they prepared themselves before taking the courses. It is helpful because as maintained by $\mathrm{Vu} \&$ Rochelle (2015), students with more positive attitudes and motivation will have better language learning strategies, helping them to master the target language.

However, it does not mean that all English-major students will have strong motivation and positive attitudes toward language learning. As shown by Ngo et al. (2017), being English-major-students does not mean one has a high level of intrinsic motivation. Individuals who are obligated to learn English because they merely want to pass the exams or else may quit learning as soon as possible (Deci \& Ryan, 2012). Thus, it seems important for teachers to foster students 'motivation despite their majors.

Although some respondents admitted that they were once demotivated due to the pandemic and online learning, the respondents of the present study used several methods to maintain their motivation and positive attitudes toward EFL learning during the Covid-19 pandemic. Below are methods are taken by the respondents of the present study to maintain their motivation and positive attitudes:

"I often read some conversation groups on social media. The groups I join are mostly about gaming, but the people there generally talk about everything. From there I learn about their struggles and stories. Seeing people always trying their best to do their activities 
in this difficult situation [to] keep my motivation up." (Respondent 1)

"Consistent, practice all the time and looking for other English references." (Respondent 3)

"For some people, it [is] kind of boring if you learning English in front of a screen (laptop or cellphone) and I can't express myself freely in the screens. But now, Zoom and other video conferences apps are available to help us express our English." (Respondent 6)

"If I feel bored when studying seriously, so I learn English through social media, such as TikTok, Twitter, Instagram, YouTube, or film." (Respondent 7)

"Maybe sometimes I have a rough day, but I never let my body down because of a bad thing. I always believe that storm will always change into a rainbow. I usually imagine all that I want to be in the future before I sleep, and thinking about my desire that I want to realize nearly also in the future." (Respondent 8)

\section{Intrinsic factors:}

Besides extrinsic factors, the respondents are also intrinsically motivated to learn English. Following are some of their comments:

"I find myself so intriguing to learn English, even if I already learned the previous subject. There is always something you were missing or forgotten and it's so refreshing to learn it again." (Respondent 1)

"I am happy to learn English because learning English is one of my passion." (Respondent 8)

"I learn English because I love the language. Not only the language, I like the people, the culture, the country, etc. I realize that learning the English language is very important since I was in junior high school..." (Respondent 9) 
As shown by the above comments, the respondents may have a moderate level of intrinsic motivation. Nevertheless, it does not seem as significant as their extrinsic motivation.

\section{Discussion}

The above results show that some respondents are extrinsically motivated to learn English because they want to obtain better jobs, communicate with people from various countries, and study overseas. Similar results were obtained by a study by Nguyen \& Habók (2017) on the motivation of a group of Vietnamese non-English-major students motivation to learn English. Their results show that most participants are motivated to learn English because they think it may help them get a better career, study opportunities, and communicative needs. Similarly, the results of the present study resonate with several previous studies (Chairat, 2015; Liu \& Huang, 2011; Ngo et al., 2017).

On the other hand, a study by Tran \& Baldauf (2007) showed that students were mostly motivated because they were required to learn English. It contradicts the results of the present study. Several factors may affect the differences. Firstly, the present students may have more awareness of the importance of English language mastery for their future. Instead of being forced, students seem to learn English because they know it will be beneficial for their future. Secondly, as suggested by Nguyen \& Habók (2017), the shift from the traditional language approach to the integrated learning model at universities may influence students ' motivation. A study by Adara, Nuryadi, \& Nasution (2019) shows that students are more motivated to learn English in the university because their tutors provided a more diverse teaching approach that caters the improvement of four skills (reading, writing, speaking, listening) than their high school teachers who only focused on teaching English grammar. In addition, socio-cultural contexts where English has a dominant position in society (Le \& Chen, 2018; Nguyen, 2017) may affect students 'motivation. The results of the present study show that the respondents are aware of the position of English mastery in society. Nevertheless, students 'motivation still needs to be encouraged by 
universities or schools by providing them with an integrated teaching approach that supports the improvements of students 'English skills.

Related to intrinsic factors, similar results were shown by Truong's (2016) study toward a group of Vietnamese EFL learners. His participants achieved a certain level of English fluency and were motivated to learn English because they want to get better jobs. The results of a study by Ngo et al. (2017) also show a moderate level of intrinsic motivation among their participants. In addition, a study by Mat S (2014) describes how a group of Malaysian EFL learners are more motivated by extrinsic factors than intrinsic ones. His results corresponded with other studies which specifically analyze EFL motivation 'contexts in Malaysia (Bidin et al., 2009; Zubairi \& Sarudin, 2009). It can be said that the results of the present study share similarities with studies conducted in other countries.

It has been argued that intrinsic motivation is psychologically better because learners are motivated due to their interests instead of other external factors which can be a subject of change. The results of Ngo et al. (2017) illustrate how intrinsically motivated students spend more time and effort to master English. In addition, Nguyen \& Habók (2017) remark that internally motivated students display higher levels of motivational orientations than externally motivated ones. However, it does not mean that being extrinsically motivated is less than being intrinsically motivated. In this regard, although being intrinsically motivated has been argued as better because it is regarded as one that fulfills the psychological needs (Deci \& Ryan, 2000), it does not mean that the participants of the present study are less motivated than ones who show high levels of intrinsic motivation. It is because both types of motivation are important. After all, they can support each other (Adara \& Haqiyah, 2021). Kim (2007) argues that learning English should be motivated by the interest in language and socially constructed needs (getting better jobs, communicating with people) because it can help students embody their motives into specific goals which is the mastery of language. It can be said that despite being less intrinsically motivated, students still need to have extrinsic factors which motivate them to learn English. 
Related to the above factors, some alternatives can be done to support students 'extrinsic motivation. The results of Carreira's (2006) study illustrate the contribution of external factors such as education, teachers, parents, peers, and the classroom toward the decrease of students 'motivation. Besides that, Mat S (2014) depicts the importance of teachers as ones who motivate students to look forward to English lessons. In this regard, teachers seem to influence students 'motivation significantly (Khazaie \& Mesbah, 2014; Poornima et al., 2016) through a series of techniques or strategies that can motivate students. In this regard, teachers can prepare activities or tasks which are meaningful or challenging for them (Cheng \& Dörnyei, 2007; Dornyei \& Csizér, 2002; Mulalić \& Obrali, 2016). For example, teachers can integrate songs into English lessons. A study by Adara (2020) shows an improvement in students 'motivation after songs are integrated into the lessons. Similar results are shown in the studies of Dzanic \& Pejić (2016) as well as Chen $\&$ Chen (2009). The above points show the importance of teachers to motivate students.

In addition, teachers can maintain students 'motivation by keeping in touch with their students regularly. During the Covid-19 pandemic, people were forced to socially distance themselves, making classrooms resort to online classrooms. This can lead to students and teachers being isolated from each other and making relationships more distant. A study by Adara \& Najmudin (2020) describes how online learning may lead to students 'demotivation as they could not meet their teachers and peers. Some teachers, as a part of motivational strategies, keep in touch with their students through online chatting applications (Adara et al., 2021). Although it seems less than ideal because it cannot entirely replace real-life connections, it can bridge the communication gap between students and teachers during the Covid-19 pandemic. The weight of evidence shows the influence of teachers on the improvement of students 'motivation. Related to the present study, it seems imperative for teachers to provide better support for students 'motivation so that they can maintain their motivation during the Covid-19 pandemic.

In addition to activities or tasks, technology can be a helpful source to improve students 'motivation. Adara \& Haqiyah's (2021) study on the effects of CALL (Computer Assisted Language Learning) toward the 
improvement of students 'motivation illustrates the positive correlation between the integration of CALL in EFL classrooms and students' motivation. Several studies have shown the positive impacts of technology toward students 'motivation in EFL learning (Başöz \& Çubukçu, 2014; Fatemi Jahromi \& Salimi, 2013; Tavakoli et al., 2019). Therefore, besides providing encouraging activities or tasks to students, it seems imperative for teachers to integrate technology into the classrooms to improve students 'motivation. Groves (2010) argues that extrinsic and intrinsic motivation are related to each other. When students are extrinsically motivated for example having supportive teachers or a learning environment, they will develop sincere interests in language learning, resulting in intrinsic motivation. However, simply integrating technology into classrooms may not be a quick solution to improve students 'motivation during the Covid-19 pandemic. It is because implementing technology is a requirement during the Covid-19 pandemic as online classrooms become the new normal. In addition, constant use of technology during online classrooms may lead to students 'fatigue (Adara \& Najmudin, 2020). Therefore, it seems important for teachers to choose suitable technology that can cater to their students 'needs and avoid fatigue. By doing those things, teachers can keep maintaining students 'motivation while integrating technology into the classrooms.

The results show several solutions conducted by the respondents to maintain their motivation and positive attitudes during the Covid-19 pandemic. It can be seen that the respondents use technology such as social media and online applications to maintain their motivation. In addition, they maintain their motivation by reminding them of their goals to master their language learning goals. Affirming the benefits of mastering the target language seems beneficial for students (Alqahtani, 2017). In this sense, teachers can encourage students to remember their language learning goals as well as the benefits of language mastery such as getting better jobs or traveling abroad. The findings of the present study indicate that the respondents used various ways to maintain their motivation and positive attitudes.

Related to the above findings, technology has been argued as beneficial to improve learners 'motivation. A study by Li (2017) on the 
Reza Anggriyashati Adara, Novita Puspahaty: How EFL Learners Maintain Motivational

Factors and Positive Attitudes During COVID-19 Pandemic: A Qualitative Study - 291

use of social media in teaching and learning activities shows that YouTube is mostly used by students to look for course-related materials. In addition, a study by Slim \& Hafedh (2019) points how Facebook, a social media website, causes positive responses and a high satisfaction level when it is integrated into classrooms. Furthermore, social media is impactful for improving collaborative learning, interactivity with peers and teachers as well as online knowledge sharing behavior (Ansari \& Khan, 2020). Nevertheless, teachers still need to guide students who learn English through social media. The provision of teachers 'guidance will help students navigate social media learning. For example, teachers can ask students to watch a video on social media before the class and discuss it later. In addition, they can ask students to note the use of language in social media. Teachers can also find some educational social media accounts which can be beneficial for language learning.

\section{CONCLUSION}

Covid-19 pandemic poses a new challenge to EFL learning and teaching in Indonesia. As students and teachers are forced to resort to online classrooms, it can affect their motivation and attitudes significantly. The present study aimed to investigate how a group of EFL learners in Indonesia maintained their motivation and positive attitudes during the Covid-19 pandemic. By investigating those variables, teachers and researchers may gain more insights on improving students' motivation. The present study applied a qualitative method by interviewing ten respondents who majored in English literature from a private university in Indonesia. The findings of the present study indicate that the respondents were motivated to learn English because they want to get better jobs, study abroad, communicate with people from different countries, and have an interest in language learning. In addition to displaying a relatively high level of positive attitudes toward EFL learning, the respondents maintained their motivation and positive attitudes by learning English through social media and affirming their language learning goals. 


\section{REFERENCES}

Adara, R. A. (2020). Enhancing EFL Learners 'Motivation through Songs. IJEE (Indonesian Journal of English Education), 7(2). https://doi.org/10.15408/ijee.v7i2.17321

Adara, R. A. (2019). Motivational Factors to Learn English among University Students in An Urban Area. Sukma: Jurnal Pendidikan, 3(2). https://doi.org/10.32533/03203.2019

Adara, R. A., \& Najmudin, O. (2020). ANALYSIS ON THE DIFFERENCES IN EFL LEARNERS 'DEMOTIVATING FACTORS AFTER COVID 19 PANDEMIC. Ta'dib, 23(2). https://doi.org/10.31958/it.v23i2.2373 Adara, R. A., Nuryadi, N., \& Nasution, R. A. (2019). Investigating the Difference in Demotivation Factors: A Case Study of Two Groups of Indonesian EFL Learners. Journal of English Language Studies, 4(2). https://doi.org/10.30870/jels.v4i2.6228

Adara, R., \& Haqiyah, A. (2020). The Effects of Integrating Digital Storytelling to Students 'Motivation. Edukasi: Jurnal Pendidikan Dan Pengajaran. https://doi.org/10.19109/ejpp.v7i2.6023

Alqahtani, A. F. (2017). The L2 Motivational Self System and Religious Interest among Saudi Military Cadets: A Structural Equation Modelling Approach. International Journal of English Linguistics, 7(5). https://doi.org/10.5539/ijel.v7n5p84

Ansari, J. A. N., \& Khan, N. A. (2020). Exploring the role of social media in collaborative learning the new domain of learning. Smart Learning Environments, 7(1). https://doi.org/10.1186/s40561-020-00118$\underline{7}$

Baldauf Jr., R. (2007). Demotivation: Understanding Resistance to English Language Learning - The Case of Vietnamese Students. The Journal of Asia TEFL, 4(1).

Barak, M., Watted, A., \& Haick, H. (2016). Motivation to learn in massive open online courses: Examining aspects of language and social engagement. Computers \& Education, 94. https://doi.org/10.1016/j.compedu.2015.11.010

Basoz, T., \& Cubukcu, F. (2014). The effectiveness of computer-assisted instruction on vocabulary achievement. Mevlana International 
Reza Anggriyashati Adara, Novita Puspahaty: How EFL Learners Maintain Motivational

Factors and Positive Attitudes During COVID-19 Pandemic: A Qualitative Study - 293

Journal

of

Education,

$4(1)$.

https://doi.org/10.13054/mije.13.77.4.1

Bidin, S., Jusoff, K., Aziz, N. A., Salleh, M. M., \& Tajudin, T. (2009).

Motivation and Attitude in Learning English among UiTM Students in the Northern Region of Malaysia. English Language Teaching, 2(2). https://doi.org/10.5539/elt.v2n2p16

Bradford, A. (2007). Motivational orientations in under-researched FLL contexts: Findings from Indonesia. RELC Journal, 38(3). https://doi.org/10.1177/0033688207085849

Carrió-Pastor, M. L., \& Mestre, E. M. M. (2014). Motivation in Second Language Acquisition. Procedia - Social and Behavioral Sciences, 116. https://doi.org/10.1016/i.sbspro.2014.01.201

Chairat, P. (2015). Attitudes and Motivation of Non-English Major Students towards Learning English as a Foreign Language: A Case Study. American Journal Experts, 1(1).

Chen, Y.-C., \& Chen, P.-C. (2009). The effect of English popular songs on learning motivation and learning performance. WHAMPOA - An Interdisciplinary Journal, 56.

Cheng, H.-F., \& Dörnyei, Z. (2007). The Use of Motivational Strategies in Language Instruction: The Case of EFL Teaching in Taiwan. Innovation in Language Learning and Teaching, 1(1). https://doi.org/10.2167/illt048.0

Deci, E., \& Ryan, R. (1985). Intrinsic Motivation and Self-Determination in Human Behavior. Perspectives in Social Psychology.

Deci, E. L., \& Ryan, R. M. (2012). Motivation, Personality, and Development Within Embedded Social Contexts: An Overview of SelfDetermination Theory. In The Oxford Handbook of Human Motivation.

https://doi.org/10.1093/oxfordhb/9780195399820.013.0006

Dincer, A., \& Yesilyurt, S. (2017). Motivation to Speak English: A SelfDetermination Theory Perspective. PASAA: Journal of Language Teaching and Learning in Thailand, 53. https://doi.org/10.14456/pasaa.2017.1

Dörnyei, Z. (2014). The psychology of the language learner: Individual differences in second language acquisition. The Psychology of the 
Language Learner: Individual Differences in Second Language Acquisition, 1-270. https://doi.org/10.4324/9781410613349

Dörnyei, Z., \& Csizér, K. (2002). Some Dynamics of Language Attitudes and

Motivation: Results of a Longitudinal Nationwide Survey. Applied Linguistics, 23(4). https://doi.org/10.1093/applin/23.4.421

Dzanic, N. D., \& Pejic, A. (2016). The Effect of Using Songs On Young Learners and Their Motivation for Learning English. NETSOL: New Trends in Social and Liberal Sciences, 1, 40-54. https://doi.org/10.24819/netsol2016.8

Ellis, R. (2006). Current Issues in the Teaching of Grammar: An SLA Perspective. TESOL Quarterly, $40(1)$.

https://doi.org/10.2307/40264512

Escobar Fandiño, F. G., Muñoz, L. D., \& Silva Velandia, A. J. (2019). Motivation and E-Learning English as a foreign language: $\mathrm{A}$ qualitative study. Heliyon, 5(9). https://doi.org/10.1016/j.heliyon.2019.e02394

Gusmuliana, P., Apriani, E., \& Syafryadin, S. (2021). Improving Students Speaking Motivation by Using Role Play Technique at Institute Islamic in Indonesia.

Hartshorn, \& McMurry. (2020). The Effects of the COVID-19 Pandemic on ESL Learners and TESOL Practitioners in the United States. International Journal of TESOL Studies. https://doi.org/10.46451/ijts.2020.09.11

Hibatullah, O. F. (2019). The Challenges of International EFL Students to Learn English in a Non-English Speaking Country. Journal of Foreign Language Teaching and Learning, 4(2). https://doi.org/10.18196/ftl.4240

Kazantseva, E. A., Valiakhmetova, E. K., Minisheva, L. V, Anokhina, S. Z., \& Latypova, E. M. (2016). A survey-based study of motivation and attitude to learning a second language at UFA state university of economics and service. 2016, 1-9.

Khazaie, Z. M., \& Mesbah, Z. (2014). The relationship between Extrinsic vs. Intrinsic motivation and strategic use of the language of Iranian intermediate EFL learners. Theory and Practice in Language Studies, 4(1). https://doi.org/10.4304/tpls.4.1.99-109

Lamb, M. (2016). Motivation (pp. 324-338). 
Reza Anggriyashati Adara, Novita Puspahaty: How EFL Learners Maintain Motivational Factors and Positive Attitudes During COVID-19 Pandemic: A Qualitative Study - 295

Le, T. T., \& Chen, S. (2018). English Tertiary Education in Vietnam (J. Albright (ed.)).

Routledge. https://doi.org/10.4324/9781315212098

Liu, M., \& Huang, W. (2011). An Exploration of Foreign Language Anxiety and English Learning Motivation. Education Research International, 2011. https://doi.org/10.1155/2011/493167

Loewen, S., \& Reinders, H. (2011). Key Concepts in Second Language Acquisition. In Key Concepts in Second Language Acquisition. https://doi.org/10.1007/978-0-230-34627-7

MacIntyre, P. D., \& Serroul, A. (2014). 11. Motivation on a Per-Second Timescale: Examining Approach- Avoidance Motivation During L2 Task Performance. In Motivational Dynamics in Language Learning. Multilingual Matters. https://doi.org/10.21832/9781783092574$\underline{013}$

Mantiri, O. (2015). Key to Language Learning Success. Journal of Arts and Humanities, 4(01). https://doi.org/10.18533/journal.v4i01.629

Mat, S. H. C. (2014). Attitudes and Motivation Towards Learning English Among FELDA School Students.

Mulalić, A., \& Obralic, N. (2016). The Relationship Between Motivation Components and Preferred Learning Components among Students at the International University of Sarajevo. Epiphany, 9(1). https://doi.org/10.21533/epiphany.v9i1.212

Nafi, J., Qabaja, Z., \& Al-Kar, H. (2016). Attitudes of Palestinian Undergraduate Students Towards Native and Non-Native English Language Teachers and Their Relation to Students 'Listening Ability. Journal of Education and Practice, 7, 27-42.

Nassaji, H. (2015). Qualitative and descriptive research: Data type versus data analysis. Language Teaching Research, 19(2). https://doi.org/10.1177/1362168815572747

Ngo, H., Spooner-Lane, R., \& Mergler, A. (2017). A comparison of motivation to learn English between English major and non-English major students in a Vietnamese university. Innovation in Language Learning and Teaching, 11(2). https://doi.org/10.1080/17501229.2015.1094076 
Nguyen, N. T. (2017). Thirty Years of English Language and English

Education in Vietnam. English Today, 33(1). https://doi.org/10.1017/S0266078416000262

Nguyen, S. Van, \& Habók, A. (2021). Vietnamese non-English-major students 'motivation to learn English: from activity theory perspective. Heliyon, 7(4). https://doi.org/10.1016/j.heliyon.2021.e06819

Poornima, B., Jayaraman, H., \& A, D. A. K. (2016). Factors Influencing Second Language Learning Among Urban European Language Learners: A Qualitative Study. International Journal of Indian Psychology, 3(3). https://doi.org/10.25215/0303.120

Révész, A. (2012). Coding Second Language Data Validly and Reliably. In Research Methods in Second Language Acquisition: A Practical Guide. https://doi.org/10.1002/9781444347340.ch11

Slim, H., \& Hafedh, M. (2019). Social media impact on language learning for specific purposes: A study in English for business administration. Teaching English with Technology, 19(1).

Taufik, M., Rijal, A. S., Dahniar, D., \& Apriani, E. (2021). The Effectiveness of Learning English Using LMS Google Classroom during Covid-19 Pandemic. AL-ISHLAH: Jurnal Pendidikan, 13(2), 960-970.

Thang, S. M., Gobel, P., Nor, F. M., \& Suppiah, V. L. (2011). Students'attributions for success and failure in the learning of English as a Second Language: A comparison of undergraduates from six public universities in Malaysia. Pertanika Journal of Social Science and Humanities, 19(2).

Truong, B. . (2016). The Motivation of Vietnamese university Students to Learn English: a Study Using the Expectancy-Value Model of Academic Motivation. Newcastle.

Vu Thi Ngoc, L., \& Rochelle Irene, G. L. (2015). The role of attitude, motivation, and language learning strategies in learning English as a Foreign Language among Vietnamese college students in Ho Chi Minh City. Asian Journal of English Language Studies (AJELS), 3.

Waninge, F., Dörnyei, Z., \& De Bot, K. (2014). Motivational Dynamics in Language Learning: Change, Stability, and Context. The Modern Language Journal, 98(3). https://doi.org/10.1111/modl.12118 
Reza Anggriyashati Adara, Novita Puspahaty: How EFL Learners Maintain Motivational Factors and Positive Attitudes During COVID-19 Pandemic: A Qualitative Study - 297

Yang, X. (2012). Attitude and Motivation in L2 Learning among Ummaster Students. International Journal of Management and Sustainability, $1(1)$.

Yulia, Y. (2013). TEACHING CHALLENGES IN INDONESIA: MOTIVATING STUDENTS AND TEACHERS 'CLASSROOM LANGUAGE. Indonesian Journal of Applied Linguistics, 3(1). https://doi.org/10.17509/ijal.v3i1.186

Zubairi, A. M., \& Sarudin, I. H. (2009). Motivation to learn a foreign language in Malaysia. GEMA Online Journal of Language Studies, $9(2)$. 
298 | ENGLISH FRANCA, Vol. 5, No. 2, 2021 